\title{
Potential Curative Role of Chemotherapy in Patients with Metastatic Colorectal Cancer Who Had Complete Response to First-line Treatment
}

\section{Birinci Hat Kemoterapi ile Tam Yanıt Alınan Metastatik Kolorektal Kanserli Hastalarda Kemoterapinin Potansiyel Küratif Rolü}

\author{
Umut Varol, Ahmet Alacacıoğlu, İbrahim Yıldız, Mustafa Oktay Tarhan \\ İzmir Katip Çelebi Üniversitesi, Atatürk Eğitim Ve Araştırma Hastanesi, Tıbbi Onkoloji Kliniği, İzmir, Türkiye
}

Dergiye ulaşma tarihi: 09/10/2014 Dergiye kabul tarihi:25/10/2014, DOI: 10.5505/aot.2014.08370

Anahtar Kelimeler: Tam yanıt; Kolorektal kanser; Karaciğer metastazları

Key words: Complete response; Colorectal cancer; Hepatic metastases

\section{To Editor,}

Here, we report on a case of multiple hepatic metastases from rectal cancer that showed complete response to chemotherapy. A 46year-old male patient was admitted to our hospital and diagnosed with rectal cancer and simultaneous multiple hepatic metastases. As the patient had wild-type KRAS mutation status, systemic chemotherapy by irinotecan with fluorouracil and folinic acid (FOLFIRI) plus cetuximab was begun via central venous port. After 3 courses of FOLFIRI plus cetuximab, abdominal computed tomography (CT) showed remarkable reduction in size of liver metastases. After completing 6 courses of the same regimen, both metastases and the primary tumor was not detected by Positron Emission Tomography- CT imaging. The radiologic complete response (CR) was also confirmed by other diagnostic modalities such as magnetic resonance imaging of the abdomen and pelvis and, rectosigmoidoscopy. Thereafter, primary tumor and hepatic metastatic sites were operated and the same chemotherapy regimen was continued for another 3 months.

For the treatment of metastatic colorectal cancer (mCRC), recent advances in chemotherapy have been demonstrated to achieve a high response rate. Despite the recognition of the potential for long-term survival after surgical resection of metastatic disease, chemotherapy is still not considered to provide a sufficient long-term survival for most patients who had unresectable liver metastases (1). However, during chemotherapy, some colorectal liver metastases may disappear on radiologic follow-up and this disappearance may represent a CR. Thus, we need predictive factors in order to stratify patients who are likely to benefit from such treatment. It is speculated that a small size and a low level carcinoembryonic antigen may predict a good response to chemotherapy for CRC patients who had unresectable liver metastases. Additionally, in cases with relatively large tumor burden, EGFR antibody together with combination chemotherapy can be an effective first-line treatment and is a systemic chemotherapy option to cure liver metastasis from CRC (2).

Dy et al. evaluated the clinical characteristics and survival outcomes of locally advanced or metastatic colorectal cancer patients who had achieved a CR to systemic treatment either alone or with multimodality approach. They found that among 1,508 patients who had CR to systemic chemotherapy alone (4\%) achieved impressive survival outcomes similar to those seen in patients who attained a CR status after multimodality treatment (2\%) (3). In another retrospective review of $2751 \mathrm{mCRC}$ patients, patients who achieved CR with chemotherapy and were not submitted to any surgical or interventional procedures directed to the metastatic sites were analyzed. The 5-year 
interventional procedures directed to the metastatic sites were analyzed. The 5-year overall survival rate for all patients was $10.8 \%$ and six of them $(0.24 \%)$ achieved a sustained complete response after chemotherapy alone (all 6 with fluoropyrimidines and 2 with irinotecan) (4). Bernoist et al. evaluated 586 patients treated for colorectal liver metastases and found that among 66 patients whose hepatic metaseses were disappeared on CT scan after chemotherapy, 20 had persistent macroscopic disease at surgery. Overall, persistent macroscopic or microscopic residual disease or early recurrence in situ was observed in $55(83 \%)$ of 66 patients (5). In the phase 3 Fire III study, CR was observed in $4 \%$ of the patients treated with FOLFIRI plus cetuximab whereas $1 \%$ in the FOLFIRI plus bevacizumab arm (6). So, cure with chemotherapy alone is possible for a very small number of patients with metastatic colorectal cancer. However, although improved chemotherapies are increasing complete response rates, long-term survival data to determine the potential curative role of chemotherapy alone is lacking and the impact of modern chemotherapy on durable complete responses will require additional follow up.
For this reason, local treatment options like radiotherapy or surgical interventions have to be used whenever considered necessary.

\section{Conflict of interest: None}

\section{References}

1. Tanida $\mathrm{T}$, Ohue $\mathrm{M}$, Noura $\mathrm{S}$, et al. Long-term complete response of unresectable liver metastases from colorectal cancer. Hepatogastroenterology 2010; 57:764-7

2. Auer RC, White RR, Kemeny NE, et al. Predictors of a true complete response among disappearing liver metastases from colorectal cancer after chemotherapy. Cancer 2010;116:1502-9

3. Dy GK, Krook JE, Green EM, et al. Impact of complete response to chemotherapy on overall survival in advanced colorectal cancer: results from Intergroup N9741. J Clin Oncol 2007;25:3469-74

4. Ferrarotto R, Pathak P, Maru D, et al. Durable complete responses in metastatic colorectal cancer treated with chemotherapy alone. Clin Colorectal Cancer 2011;10:178-82

5. Benoist $\mathrm{S}$, Brouquet $\mathrm{A}$, Penna $\mathrm{C}$, et al. Complete response of colorectal liver metastases after chemotherapy: does it mean cure? J Clin Oncol 2006;24:3939-45

6. Heinemann V, von Weikersthal LF, Decker T, et al. FOLFIRI plus cetuximab versus FOLFIRI plus bevacizumab as first-line treatment for patients with metastatic colorectal cancer (FIRE-3): a randomised, open-label, phase 3 trial. The Lancet Oncology 2014;105:1065-75 